\title{
Race, Reading, and the Book Lovers Club, Des Moines, Iowa, 1925-1941
}

\author{
CHRISTINE PAWLEY
}

BOOKS BY AND ABOUT AFRICAN AMERICANS were hard to locate in the 1920s and 1930s. Few public libraries provided materials of interest to black readers. In 1925, ten members of the segregated Blue Triangle Branch of the Young Women's Christian Association (YWCA) of Des Moines, Iowa, created their own reading opportunities by forming the Book Lovers, a reading club that met to discuss a wide range of literature. The reading materials available through the YWCA's Blue Triangle Branch from the 1920s to the early 1940s, especially the materials on race, suggest that through books the Book Lovers imagined multiple identities for themselves - as African Americans, as Iowans, and as educated, cultured citizens. ${ }^{1}$

For these black readers, print represented a force for positive social change. During the ostensibly peaceful period between

1. The papers of the Blue Triangle Branch of the Des Moines YWCA, and of the Book Lovers Club, are part of the Records of the YWCA of Greater Des Moines, in the Iowa Women's Archives, University of Iowa Libraries, Iowa City, Iowa (hereafter cited as YWCA Records). As well as scrapbooks, minutes of meetings, and newspaper clippings, the club's papers include mimeographed programs that list the titles and authors of books that the club chose for review for eight years between 1933 and 1941 (programs for 1936 and 1939 are missing). These combined lists contain 211 different titles (three had duplicates), including titles suggested as possible substitutes. Five of these titles were unidentifiable, leaving 206 for further analysis. Other information about the Book Lovers can be found in the Public Library of Des Moines (PLDM) Archives.

THE ANNALS OF IOWA 65 (Winter 2006). (C) The State Historical Society of Iowa, 2006. 
the two world wars, African Americans experienced wrenching upheaval and social disruption. Terrorized in the South, nearly a million fled north during the 1920s, seeking safety, better work opportunities, and an education for their children. ${ }^{2}$ Yet there, too, they were subject to unavoidable humiliation and routinely excluded from public accommodations. As conditions worsened with the onset of economic depression in the 1930s, black Americans fought against deeply entrenched cultural and social practices that persistently denied them full rights as citizens. Print culture was one way some resisted racism. Through reading and writing, black men and women publicized, debated, and protested the oppressive conditions of their everyday existence, as books and newspapers written by and for the black community became vehicles for conceiving of radical social transformation.

The sites where African Americans encountered these materials were often segregated, however. Even where black readers had equal access to public library facilities, for instance, they were unlikely to find themselves and their interests reflected in the library collections in the way that white readers took for granted. "People like to read about themselves," commented the authors of a large-scale study of adult reading preferences published in $1931 .{ }^{3}$ But most public library collections reflected the interests of the white majority. The situation was especially dire for the young. Demeaning descriptions and illustrations pervaded the few children's books with African American characters. Children's books about African Americans that did not include such stereotypes were virtually non-existent before the 1920s, and were subsequently slow to arrive on library shelves. According to historian Cheryl Knott Malone, "It was impossible during the Jim Crow era to build a collection of children's literature that included only positive or accurate images of African Americans, a condition that persisted at least into the late 1960s." 4

2. James R. Grossman, Land of Hope: Chicago, Black Southerners, and the Great Migration (Chicago, 1989), 3-4.

3. Douglas Waples and Ralph W. Tyler, What People Want to Read About: A Study of Group Interests and a Survey of Problems in Adult Reading (Chicago, 1931), xxiii (emphasis in original).

4. Cheryl Knott Malone, “Books for Black Children: Public Library Collections in Louisville and Nashville, 1915-1925," Library Quarterly 70 (2000), 193. 
In the 1920s and 1930s, few public library directors provided access to reading materials that treated African Americans (or any other group of color) with respect. Exceptions included Ernestine Rose, the white director of Harlem's 135th Street Branch of the New York Public Library, and Vivian Harsh, the African American director of the G. C. Hall Branch of the Chicago Public Library, both of whom facilitated the development of outstanding collections of African American materials. ${ }^{5}$ By publishing bibliographies of books "By and About Negroes," Forrest Spaulding, the progressive white director of the Public Library of Des Moines (PLDM), also encouraged black and white readers to understand how racism systematically structured American society. ${ }^{6}$

In 1938 Spaulding crafted a document that he titled "The Library's Bill of Rights," which was to have far-reaching consequences for librarianship. The Library Bill of Rights is often interpreted as a response to the twin threats of fascism and communism, but the state of race relations in America must also have been on Spaulding's mind when he drafted the first article to read: "Books and other reading matter . . . shall be chosen from the standpoint of value and interest to the people of Des Moines and in no case shall selection be based on the race or nationality, political or religious views of the writers." 7 In June of the following year, the PLDM's Library Bill of Rights became the blueprint for a similar document that Ernestine Rose presented for adoption by the American Library Association's Council at the association's annual convention. ${ }^{8}$

Still, the efforts of librarians such as Rose, Harsh, and Spaulding to encourage more attention to race were seldom reflected in the standard collecting guides librarians routinely consulted during the 1930s for advice on how to build their collections, such as the H. W. Wilson Company's Standard Catalog

5. Donald Franklin Joyce, "Resources for Scholars: Four Major Collections of Afro-Americana," Library Quarterly 58 (1988), 66-82.

6. Two surviving PLDM bibliographies show a mixture of fiction (16 books), nonfiction (11), drama (2), and poetry (6). YWCA Records, box 20.

7. “The Library's Bill of Rights," Library Bill of Rights 50th Anniversary Folder, 1988, PLDM Archives.

8. ALA Bulletin, 10/15/1939, 60 . 
and Fiction Catalog, or the A.L.A. Catalog. The 1926 edition of the A.L.A Catalog clustered a mere 15 titles under the general heading "Negroes," a further 4 under "Negro Songs," and 2 more under "Negro Poetry." The books on the PLDM bibliographies were also poorly represented in the standard collecting guides. For example, of the 11 books of fiction by black authors on the PLDM bibliographies that were published in time to appear in the 1931 Fiction Catalog, only 2 in fact did so.

IN SOME AREAS, the YMCAs and YWCAs provided black readers with access to books. In such cases, their efforts supplemented or substituted for local public library services. In Des Moines, the group of middle-class African American "home women" who formed the Book Lovers Club set themselves the aim of reviewing and discussing recent books. ${ }^{9}$ They met once a week at two in the afternoon on Fridays - only breaking during the hottest period of the summer - to review a variety of new books, from scholarly works on race by sociologists to popular fiction of the day. They also discussed articles they read in the National Association for the Advancement of Colored People's (NAACP's) Crisis, or the Urban League's Opportunity. They also rented out books to other members of the segregated branch. Even after the YWCA desegregated in 1947 and the Blue Triangle Branch closed, the Book Lovers remained a club exclusively for African Americans until 1958.

When the Book Lovers formed their club, the Blue Triangle Branch itself was only six years old. Although the YWCA had been a Des Moines institution since 1895, African Americans were not welcome there in the early years of the twentieth century. Designed primarily as a home away from home for young, single, Protestant women working in the city, the Des Moines YWCA envisioned its patrons as having very specific characteristics. African Americans were completely excluded, and the white women who were admitted were encouraged to conform

9. "One Hundred Years: Our Second Century - Stronger With Diversity," advertising supplement, Des Moines Register, 12/15/1994. The Book Lovers referred to themselves as "home women," as in, for example, their fall program for 1937-38. YWCA Records, box 20. 
to middle-class cultural expectations. ${ }^{10}$ In the late nineteenth century, African American women had established several selfgoverning black YWCA associations, but the formation of a national board in 1907 normalized white associations as "Central" while marginalizing black groups as "branches," thus robbing African Americans of much of their autonomy and confirming and institutionalizing Jim Crow separatism in the Midwest and elsewhere. ${ }^{11}$

The presence of Camp Dodge and Fort Des Moines during World War I made citizens of Des Moines more aware of the needs of African American soldiers and African American working women. As a result, the Des Moines Central YWCA set up a segregated branch in 1919. Two years later, the branch acquired its own building - a house located at 782 West Tenth Street, just south of Center Street, in the heart of the vibrant and close-knit African American community. First known as the Tenth Street Center and then as the Tenth Street Branch, in 1924 the facility took the name Blue Triangle Branch, at the suggestion of (white) Y secretary Leila Wilson. ${ }^{12}$ In 1925 the Blue Triangle Branch moved to more permanent quarters in a house at 1227 School Street that included "an assembly room on the main floor, with offices and kitchen," with an upper floor arranged into "two private clubrooms," and a "spacious lawn" that provided "adequate playground space, which will probably be equipped with tennis courts and other sport facilities." 13

In the late 1930s, the family of John S. Coskery donated their large and elegant home at 1407 Center Street to the YWCA for use by the Blue Triangle Branch. In 1938 the YWCA annual report noted that the Coskery House-" well kept and attractive"

10. In the first issue of the Des Moines YWCA's newsletter, for instance, the editor lauded the residents for taking advantage of classes in "German, Shakespeare, English literature and Basketry," as well as Bible Study. Inklings, 2/15/ 1905.

11. Nina Mjagkij and Margaret Spratt, eds., Men and Women Adrift: The YMCA and the YWCA in the City (New York, 1997), 12.

12. Minutes, YWCA Board of Directors, 5/9/1922, YWCA Records, box 3; YWCA Annual Meeting, 1/25/1924, ibid. Several groups started in World War I were known as Blue Triangle branches, but not all were race based. Men and Women Adrift, 289.

13. Marguerite Esters Cothorn, "The YWCA Book Lovers Club," unpublished typescript, October 1996, PLDM Archives; Des Moines Register, 9/29/1923. 


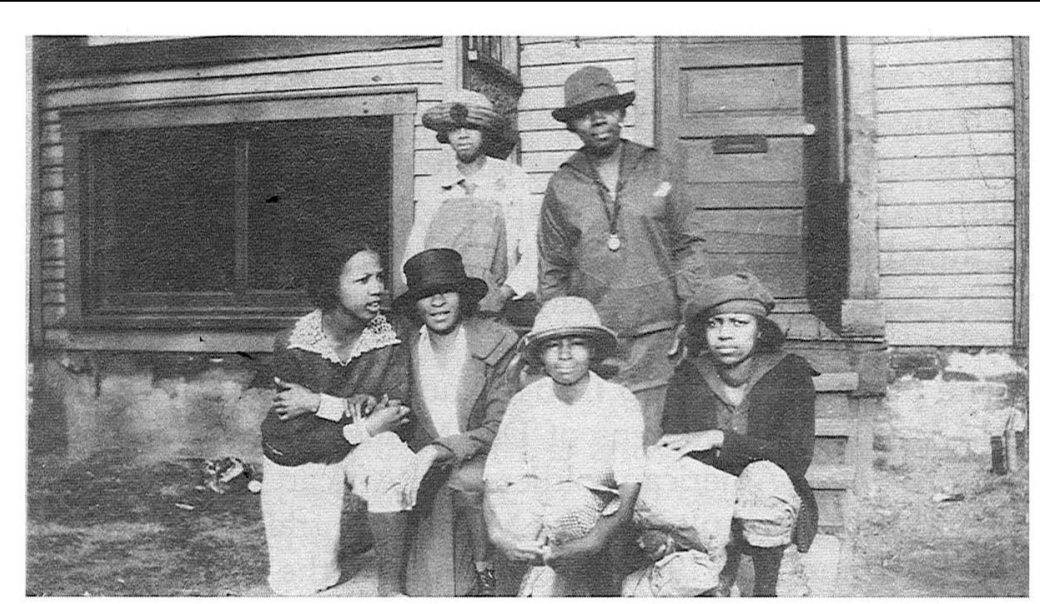

A group of young women pose in front of the building on 10th Street in Des Moines used in the 1920s for the segregated branch of the YWCA. Photo from State Historical Society of Iowa, Des Moines.

- was "always available for use of groups in the Negro community." The programs themselves provided "Negro women and girls community contacts where they are people rather than members of a minority group." Staffed by a secretary and 137 volunteers, the house included "dormitory space for three girls," as well as room for a range of activities that reached more than 400 people in 1938. Those activities included not only the weekly meetings of the Book Lovers' Club, but religious services, a weekly chorus, meetings of three "Girl Reserve Clubs," youth forums on "Social Disease, Vocations, Education for Marriage, etc.," and classes in interior decorating, handcraft, basketball, badminton, and "Parliamentary Usage."14

From the very beginning of the segregated branch, the issue of race was high on the Y's official agenda. At the (white) board of directors' meeting held on April 12, 1921, one of the directors - a Mrs. Jordan-spoke of "the enthusiasm aroused by the visit of Mrs. Winn, colored worker from national headquarters." Winn had urged the board members to facilitate more black involvement in the running of the segregated branch, empha-

14. Annual Report, 1938, YWCA Records, box 6. 


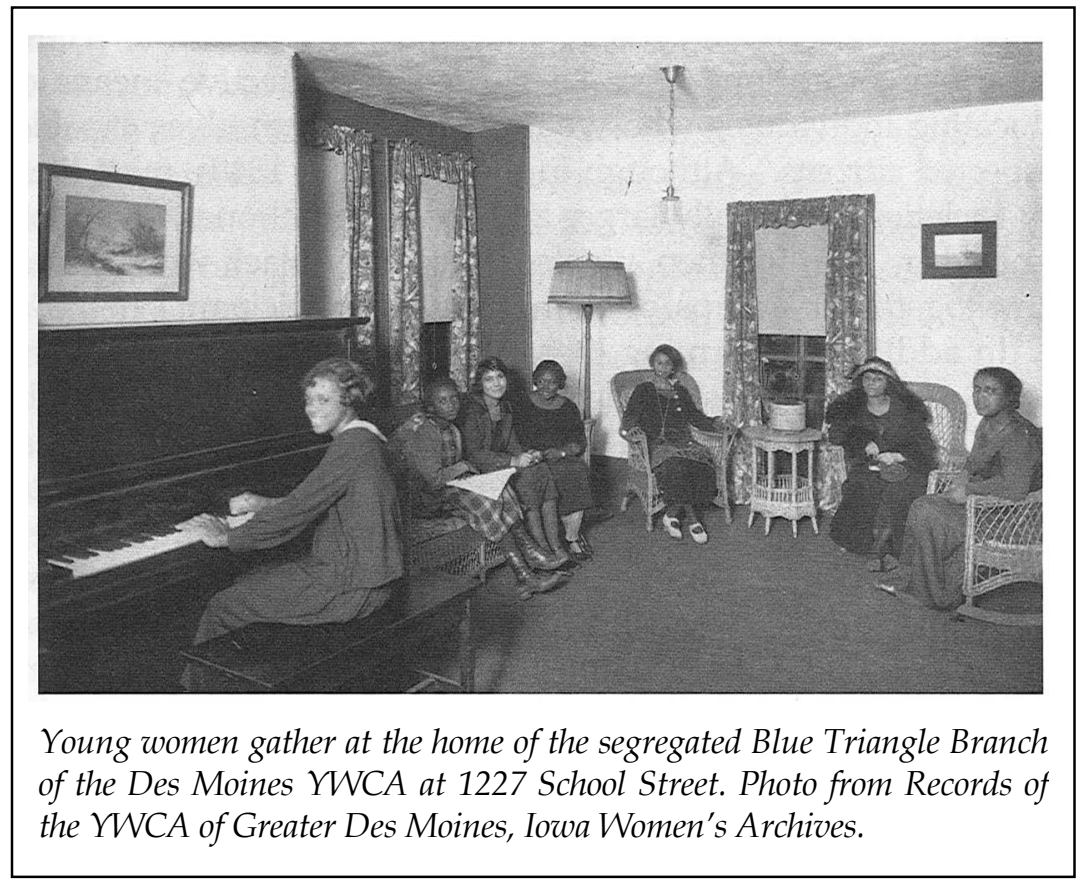

sizing "the importance of making the colored people realize their own responsibility to the association." Now Jordan pointed to the branch successes: "The progress of work among the colored girls has been remarkable when you stop to consider that the work has been started only in the last two and half years. ... The colored girls have been found to have the same desires and ideals as the white girls, with far less opportunity to express them. In nine fields the opportunity has been increased through the YWCA and the response has been wonderful." 15

Despite the patronizing tone and self-serving implications of this white-authored report, black women in Des Moines were well accustomed to running their own affairs, drawing on a long history of African American communal self-help and mutual support groups. Since the early nineteenth century, free blacks in the North had established societies to promote literacy. Members of such societies, both large and small, "planned reading lists and provided regular opportunities for black writers to pub-

15. “Regular Meeting of Board of Directors," 4/12/1921, YWCA Records, box 3. 
lish original literary creations, both orally and in print." These literary organizations were "a particularly effective means of educating individuals who would consider themselves capable, respected citizens." Although in the 1830s and 1840s, most literary societies - especially larger and more formal ones - were organized by men for men, nineteenth-century black women, too, came together in groups, often meeting in a participant's home. ${ }^{16}$

In addition to forming literary groups, African Americans in the early republic started schools, formed libraries, and published newspapers. In the 1820s and 1830s the Second Great Awakening stimulated the reading and writing of religious works among both black and white Protestants and inspired antislavery societies, temperance organizations, and evangelical Christians to set up printing presses and establish publishing companies. Some had organizational links to black churches, and focused mainly on producing printed materials for use by their congregations. ${ }^{17}$ Although the number of African American literary societies declined after the Civil War, the end of the century saw renewed activity. The club movement of the 1890s provided middle-class black women with "a forum in which to experience and express views on education [and] political action," as well as giving leading black women "visibility and space in which to address the value of 'race literature,' which, [they] believed, would help counter the destructive images fostered by a racist white press." 18

In the post-Emancipation period, black clubwomen had been primarily responding to unmet, urgent social needs for such things as childcare, orphanages, or homes for the elderly. ${ }^{19}$

16. Elizabeth McHenry, Forgotten Readers: Recovering the Lost History of African American Literary Societies (Durham, NC, 2002), 3, 18, 61.

17. Frances Smith Foster, "African Americans, Literature, and the NineteenthCentury Afro-Protestant Press," in Steven Fink and Susan S. Williams, eds., Reciprocal Influences: Literary Production, Distribution, and Consumption in America (Columbus, OH, 1999), 26-27. On the link between women's reading clubs and churches in the late nineteenth century, see Anne Ruggles Gere, Intimate Practices: Literacy and Cultural Work in U.S. Women's Clubs, 1880-1920 (Urbana and Chicago, 1997), 40-44.

18. McHenry, Forgotten Readers, 191.

19. Gerda Lerner, "Early Community Work of Black Club Women," Journal of Negro History 59 (1974), 158-59. 
But by the turn of the century, some clubwomen began to shift away from efforts primarily to promote charitable projects and towards activities more aptly characterized as social uplift. The Iowa Federation of Colored Women's Clubs (IFCWC) formed in 1903 to aid "the betterment of the home and social life of the Afro-American people," and more particularly "to secure harmony in action and co-operation among women in raising their home, moral and civil life to the highest standard." 20

During this period, middle-class African American women activists' organizational structures increasingly provided them with the leadership skills to cross the boundary that circumscribed all women - the boundary between a private, domestic world and the public world of politics, the professions, and commerce. In Iowa, influential African American women formed an elite in which formal organizational links were buttressed by familial and other informal ties. Between 1919 and 1949, the IFCWC supported a "Federation Home" for black women students at the University of Iowa, since African Americans were barred from campus housing until 1950. Student residents of the Federation Home were often close relatives of members of organizations such as the IFCWC, the Order of the Eastern Star (OES), the National Association of Colored Women (NACW), or of clubwomen from other states. Students themselves sometimes joined these organizations or received further help from members in seeking jobs or political positions. Church membership, too, helped in these endeavors. ${ }^{21}$

The way in which organizational memberships interlocked can be seen from a "Who's Who" of the Blue Triangle Branch in 1942. All of the 16 women listed as members of the branch were also members of one of two churches; half belonged to the Corinthian Baptist Church, the other half to the St. Paul African Methodist Episcopal Church. Seven were listed as active or formerly active in "Federated Club" work; three were members of

20. Kathryn M. Neal, "Unsung Heroines: African-American Women in Iowa," in Bill Silag et al., eds., Outside In: African American History in Iowa, 1838-2000 (Des Moines, 2001), 368.

21. Richard M. Breaux, "'Maintaining a Home for Girls': The Iowa Federation of Colored Women's Clubs at the University of Iowa, 1919-1950," Journal of African American History 87 (2002), 238. 
a sorority, and two of the NAACP, while one member (Victoria Hendricks) listed membership in the OES, the Daughter of Elks, the American Legion Auxiliary, and the Rebecca Court of Calenth. Some listed membership in commercial organizations; Pauline Humphrey, for example, was a member of the Iowa Beauticians League and the Des Moines Negro Chamber of Commerce. One woman listed herself as a graduate of the Tuskegee Institute, and another as having attended Drake University, yet this was surely an understatement of the group's educational attainments, since at least one-Adah Johnson-had graduated from the University of Iowa in 1908 (one of the first two black women to do so), yet her listing failed to mention that. ${ }^{22}$ Almost all of the women listed committee responsibilities, either at the $Y$ or at other organizations. Two were members of the executive committee of the YWCA Inter-racial Commission. At least two-Pauline Humphrey and Adah Johnson-were also members of the Book Lovers Club.

THE EARLY YEARS of the Book Lovers Club coincided with several movements in the development of black print culture. During the Harlem Renaissance of the 1920s, black writers, musicians, and artists used their creative expressions to protest the injustices of racial discrimination and oppression, to give voice to a sense of pride in their race, and to spread knowledge and understanding of black literature. Both The Crisis and its rival, Opportunity, published fiction, offered literary prizes, and recommended reading in regular columns. In these ways the two "quality" black magazines assumed cultural authority. Opportunity was the publication of the more conservatively inclined Urban League. Its founding editor, until he left for an academic position at Fisk University, was sociologist Charles S. Johnson. In contrast to W. E. B. Du Bois's political activism in The Crisis, Opportunity under Johnson emphasized a more detached social scientific analysis of social and economic issues. It also provided publishing space for black artists and writers, including those of the Harlem Renaissance. But its high culture tone was perhaps reflected in its circulation figures, which peaked at only about

22. The Communicator 2 (2/15-29/1988), PLDM Archives. 
11,000 in 1927-1928. ${ }^{23}$ By contrast, The Crisis had peaked in May 1919 with a readership of 100,000. But The Crisis, too, was faring badly during the 1920s. From an initial run of 1,000 in 1910, circulation shot up, and within a year had increased to 15,000. Through the 1920s, it fell steadily, however, and by 1930 it was down to $3,000.24$

In Iowa, the most established black newspaper was (and is) The Iowa Bystander. ${ }^{25}$ Founded in 1894, it came under the editorship of black lawyer John L. Thompson in 1896. For the next 20 years, until he sold the newspaper in 1919, Thompson made the Bystander a voice of protest against the growing acceptance of Jim Crow practices in Des Moines during the early part of the twentieth century. "All we ask as a race," Thompson wrote in protest against a 1913 bill to ban interracial marriage in Iowa, "is justice, equality and fair play." Thompson's criticism of D. W. Griffith's 1915 racist movie, The Birth of a Nation, influenced the city council's decision to ban its screening. ${ }^{26}$ During the period between the wars, despite financial difficulties, the Bystander (the only black newspaper in Iowa during most of the period) continued to support the demands of the NAACP and other organizations devoted to civil rights. Editor James B. Morris, though more restrained in his criticism than Thompson, made acts of discrimination against African Americans front-page news, and the paper solicited reader response in the form of reports of discrimination. As news of the Scottsboro Boys case hit the headlines, the paper called for black and white readers to join a protest meeting. ${ }^{27}$

23. Michael Fulz, "'The Morning Cometh': African American Periodicals, Education, and the Black Middle Class, 1900-1930," in James P. Danky and Wayne A. Wiegand, eds., Print Culture in a Diverse America (Urbana and Chicago, 1998), 134.

24. Ibid., 132.

25. The newspaper's name has shifted slightly several times over the course of its history. It started off in 1894 as the Iowa State Bystander, but changed to The Bystander in 1916. In 1926 it became the Iowa Bystander, and in 1972 the New Iowa Bystander. Allen W. Jones, "Equal Rights to All, Special Privileges to None: The Black Press in Iowa, 1882-1985," in Henry Lewis Suggs, ed., The Black Press in the Middle West, 1865-1985 (Westport, CT, 1996), 71-106.

26. Jones, “Equal Rights to All, Special Privileges to None," 78-79.

27. Ibid., $87-88$. 
The Bystander also occasionally offered suggestions on what to read. Sometimes it published fiction. In 1933, for instance, it serialized the white British novelist Warwick Deeping's The Challenge of Love, and also printed short stories by black writer Frank Marshall Davis. In the mid-1930s, Sonia Krutchkoff of the 135th Street Harlem Adult Education Committee in New York City wrote a "What to Read" column that the Bystander published intermittently. "We will be glad to help you solve your book problems; plan outlines for courses of study in any desired subject, or give competent direction in the choice of books," Krutchkoff wrote in an introductory letter. ${ }^{28}$ Despite the Harlem connection, her columns were not oriented toward African American authors. Rather, the columns focused on standard self-help texts (a theme in August 1933, for example, was "wise planning of the family budget"), biography, humor, and middle-brow fiction. No evidence suggests that the Bystander directly influenced the Book Lovers' selection of books, although the newspaper's consistent stand against racial injustice may well have inspired some of their reading choices. The club regularly reported its activities in the Bystander's columns, using it as a means to reach new members, and at the same time declaring to the black community the value the Book Lovers placed on the act of reading.

FROM THE BEGINNING, the Book Lovers declared that their main intent was to review recent books. That they also rented out books is evident from a notice (undated, but probably 1941) announcing that the following titles were available: Margaret Armstrong's Trelawny (1940), Bartlett's Familiar Quotations, Conrad Richter's The Trees (1940), Translations from the Chinese by Arthur Waley (1941), and two works by African American authors, Big Sea by Langston Hughes (1940), and Richard Wright's best-selling Native Son (1940). Book rental was only a sideline for the Book Lovers, but that they undertook it at all suggests that it must have been difficult for the Blue Triangle Branch's members - even perhaps for the relatively prosperous Book Lovers (most of whom could afford not to work for paid employment outside the home) - to buy books.

28. Iowa Bystander, 8/26/1933. 
The Book Lovers also encouraged public programs that featured books about race and the work of black writers. In 1932 the YWCA's Committee on Colored Work held a series of forums for the "Discussion and Study of Literature by and about Negroes and of Achievement by Them." A featured speaker at the February 24 forum was Forrest Spaulding, who spoke about the black singer Paul Robeson. The Book Lovers themselves sponsored the March 29 forum with Mrs. J. G. Browne, the YWCA's (white) president, in the chair. The program that night consisted of poetry by "Negro Women Authors," piano music by "Negro Composers," and a book review of Women Builders by Sadie I. Daniel (a set of sketches, first published in 1931, of the lives of seven black women who "have definitely contributed to the development of Negro youth in the United States"). ${ }^{29}$

In attempting to locate "Literature by and about Negroes," the Y's Committee on Colored Work (composed of white and black $Y$ members) corresponded with at least one specialized bookstore, the Warren Book Company, "Headquarters for Negro Books," on 135th Street in New York. In 1932 the committee's (white) chairwoman received a mass-produced letter from one Archie Poole (perhaps the bookstore's owner), urging the purchase of Edwin R. Embree's Brown America, published the year before by Viking Press. "It's all about how a new race is growing up in this country, a fine race of folks of mixed blooda brown race of mingled white and black parentage," wrote Poole. Appealing to a sense of race pride, Poole continued, "You can't read this book without finding your pulse beat a little faster and your backbone get a little stiffer. You can't read this book without a surge of pride for the Negro blood that's in you. It is a thrilling tale with pathos and joy - a human tale." 30 The records do not reveal the committee's response, but the letter's existence testifies to more than a passing knowledge of the infrastructure of black publishing. And the committee may have passed the recommendation along to the Book Lovers, for the club did indeed review Brown America in the fall of 1932.

29. Flyer, YWCA Records, box 20; Sadie Iola Daniel, Women Builders (Washington, DC, 1970), iii.

30. Archie Poole to Mrs. McCoy, n.d., YWCA Records, box 20. Embree was the white executive director of the Julius Rosenwald Foundation. 
Choosing to review new books was an effective way to spread information about current publications without requiring each member to acquire a copy of the book. The Book Lovers adopted a systematic approach to book reviewing. In their published program for 1937 to 1938, they set out detailed instructions on how reviews should be written. ${ }^{31}$ The guidelines indicate that the Book Lovers valued books as vehicles for the discussion of social and political questions, as well as for their literary quality. Members were interested in reading to learn as well as for pleasure. Following the instructions must have also given confidence to new members and encouraged a regular standard of presentation quality at the weekly meetings.

In a presentation that should last no more that 20 minutes, the reviewer was instructed to start by introducing the author with a "few facts about his life and other works," along with publishing information - publisher, date, price, the cover, dedication, preface, any illustrations, and "other details about make up of book." Next, she should outline the book's purpose by providing a "General idea of subject and style" and an estimate of the book's "literary or scientific value." The review should tell "enough of plot and characters to give reader idea of whether he wants to read book or not. It should not tell enough of plot to lessen interest when the story is read." The review should give details about the "Place of action, time," and "kinds of characters" and should also attempt to classify the book:

1. Is the novel a romantic love story?

2. Is it a historical novel, the chief interest of which is in the presentation of the social and political condition of a people?

3. Is it a political novel, intended to correct evils that exist in the management of the government or one of its institutions?

4. Is it a novel dealing with a social problem, racial or concerning family interest?

5. Is it a novel of character?

Finally, the reviewer should assess the book's value, first by discussing its "literary or scientific value" and, in the case of science books, summarizing the information provided by the author.

31. "On Reviewing Books," Book Lovers Club Fall Program, 1937-38, YWCA Records, box 13 . 
If, on the other hand, "the literature is fiction," the instructions continued, "what message does it have? Is the story interesting or dull, pleasing or depressing? Discuss the moral or artistic purpose, the strength of characters, the beauty of description, the form may be mentioned. Is English pure, words well chosen, plot structure defective, style pleasing, is it educational?" 32

NO SURVIVING EVIDENCE reveals how the Book Lovers selected books for review. Perhaps they chose by word of mouth, selecting books that they heard about in casual conversation or in a formal presentation at church, or at meetings of the many other organizations to which they belonged. They may have received publishers' catalogs in the mail or consulted best-seller lists or lists of books recommended by book clubs such as the Book of the Month Club or even PLDM librarians. Another possibility is that they located them through reviews in other publications. Their programs indicate that they read and discussed The Crisis and Opportunity, both of which published book reviews (Opportunity more extensively). Indeed, 32 of the Book Lovers' choices (about 16 percent of the total) were reviewed in Opportunity. In most of those cases, Opportunity reviewed the books before the Book Lovers did, but in a few instances, they were very close in time, and in at least one case the Book Lovers' review preceded Opportunity's. Although the Book Lovers may have been using Opportunity as a guide, they were clearly relying on other sources, too.

Members planned their programs well ahead, choosing and assigning titles and printing up programs at the beginning of the season. Like other readers of the time, their main preference seems to have been fiction. Of the books on the combined lists, 129 (62 percent) were fiction. Fifteen were best-sellers, including some that would retain their popularity over many years to come, such as Ernest Hemingway's For Whom the Bell Tolls (published in 1940) and Daphne Du Maurier's Rebecca (published in 1938; the Alfred Hitchcock movie starring Laurence Olivier and Joan Fontaine appeared in 1940). Most, though, subsequently lost at least some of their name recognition value, such as Iowa

32. Ibid. 


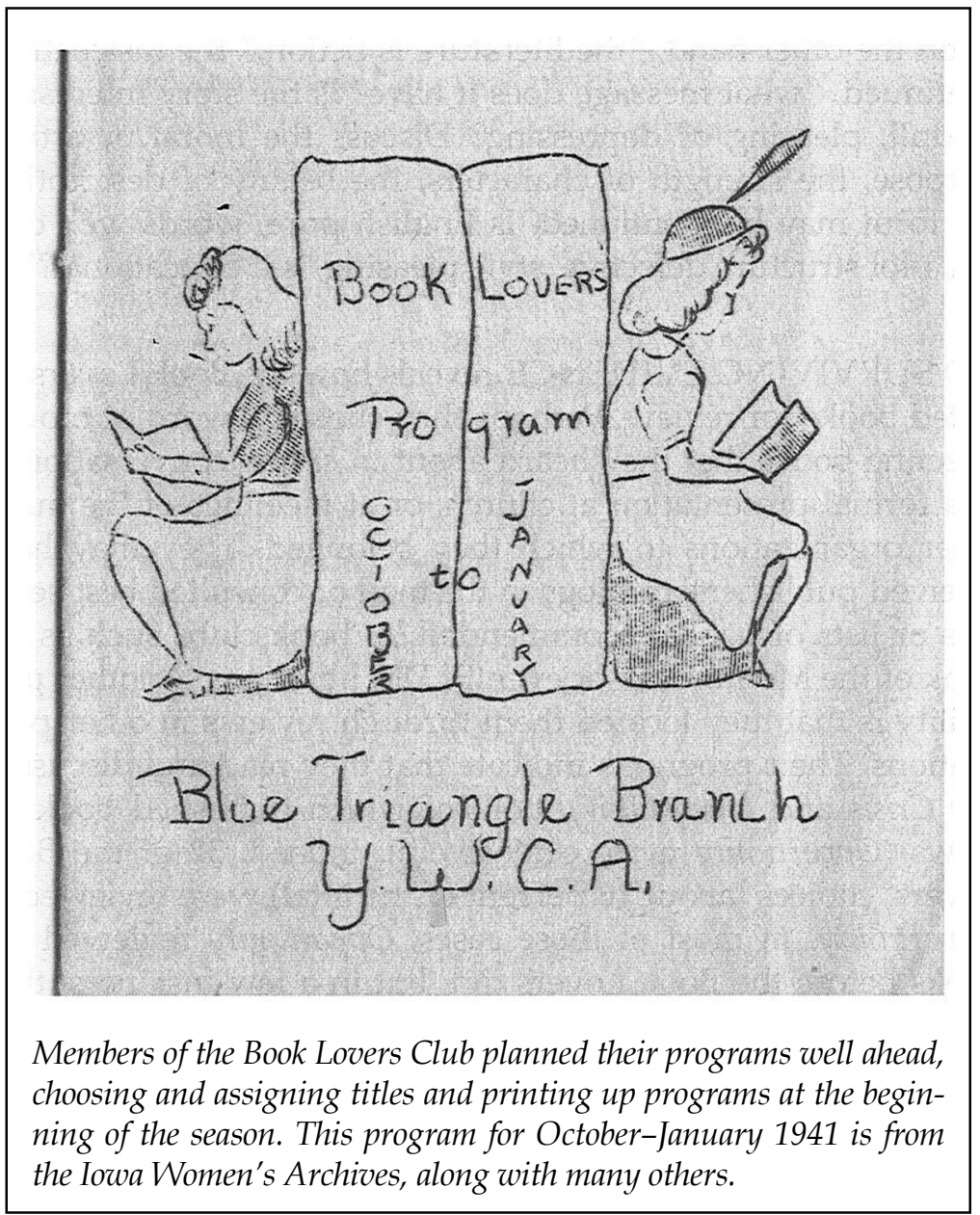

author Bess Streeter Aldrich's Miss Bishop (1933), Mazo de la Roche's The Master of Jalna (1933), and A. J. Cronin's The Keys of the Kingdom (1941). Yet others would later be mostly forgotten Ellen Glasgow's The Sheltered Life (1932), Caroline Miller's Lamb in His Bosom (1933), and Rachel Field's All This and Heaven Too (1938; released as a Warner Brothers movie in 1940).

Nonfiction best-sellers (a total of 12 titles) included two books by Anne Morrow Lindbergh - North to the Orient (a 1935 best-seller) and Listen! The Wind (a 1940 best-seller)-Mortimer Adler's How to Read a Book (also a best-seller in 1940), and Adolf 
Hitler's autobiographical Mein Kampf (a 1939 best-seller). Altogether, 28 best-sellers appeared on the Book Lovers' lists (13 percent of the total). Thirteen of their choices were also picked by the Book-of-the-Month Club, just one of a number of literary ventures that were helping to construct the "middle-brow" reader by distributing expert advice to book buyers on a commercial basis. ${ }^{33}$ Most of these were fiction, but they also chose James Adams's Epic of America (1931), Frederick Lewis Allen's Only Yesterday: An Informal History of the Nineteen-Twenties (1931), and Margaret Armstrong's biography Trelawny: A Man's Life (1940). Altogether, the Book Lovers reviewed seven biographies or autobiographies.

The Book Lovers showed some interest in poetry, reviewing six titles, of which two had local interest. In the fall of 1932 they reviewed Silk of the Corn: Poems by Members of the Iowa Federation of Women's Clubs (1932), edited by Mrs. L. Worthington Smith; in the same season they chose West of the Great Water (1931), by Paul Engle (who in 1941 became director of the University of Iowa's famed Writers' Workshop) and Harold Cooper. Altogether, they chose nine books by authors with some connection to Iowa, including two novels each by MacKinlay Kantor-Jaybird (1932), and Long Remember (1934) - and Phil Stong-State Fair (1932), and Stranger's Return (1933). They also picked Iowa author Margaret Wilson's One Came Out (1932), a novel about a prison warden assailed by doubts about the justice of executing a convicted man.

Many of the Book Lovers' choices indicated an intense interest in social and political issues and a willingness to tackle substantial works of analysis and commentary. Elizabeth McHenry points to the uses nineteenth-century African American women made of books to construct themselves as "aspiring American citizens." In her study of late twentieth-century (white) women's book clubs in Houston, Texas, sociologist Elizabeth Long notes the "identity work" that takes place when women form groups to discuss books. Often, she says, they are "searching for intel-

33. Joan Shelley Rubin, The Making of Middle-Brow Culture (Chapel Hill, NC, 1992); Janice A. Radway, A Feeling for Books: The Book-of-the-Month Club, Literary Taste, and Middle-Class Desire (Chapel Hill, NC, 1997); Jay Satterfield, The World's Best Books: Taste, Culture, and the Modern Library (Amherst, MA, 2002). 
lectual companionship." But also, and perhaps more importantly, they support each other "in a collective working-out of their relationship to the contemporary historical moment and the particular social conditions that characterize it." The relationship between reading and the construction of identity is a creative form of reflection, she emphasizes, "not simply reactive," because through such discussion the women "are imagining and expressing new insights, new definitions both of their own situations in the world and of their own desires or judgments, and new understanding of who they can or want to become." Like the black women in McHenry's historical study and the white women in Long's sociological research, the Book Lovers in the 1930s and 1940s were working out their own relationship to the "larger historical scene." 34

The Book Lovers made a conscious effort to choose books through which they could explore their identities as black Iowa women living during a period of extraordinary social upheaval. Christianity played an important part in the construction of that identity. Books with a spiritual theme included E. Stanley Jones's Christ of the Mount: A Working Philosophy of Life (1931) and Christ and Human Suffering (1933), Albert Mordell's Quaker Militant: John Greenleaf Whittier (1933), Mary Pickford's Why Not Try God (1934), and Henry C. Link's Return to Religion (1936). They also chose Edmond Fleg's exploration and celebration of Judaism, Why I Am a Jew (1929), and Hugh Redwood's God in the Shadows (1932), a Salvation Army perspective on life in the London slums. They tackled broad political and economic questions with books such as Stuart Chase's A New Deal (1932), George Solkolsky's The Tinder Box of Asia (1932), and Taliana Tchernavin's Escape from the Soviets (1934).

Above all, they were interested in race. Nineteen (9 per cent) of their titles were by black authors, and several of their other choices were by white or Asian authors who addressed racial questions. Among them was Roark Bradford, a prolific white writer of novels featuring African Americans and set in the South. Bradford's inclusion on the list illustrates the difficulty at that time of finding novels by white authors that presented

34. McHenry, Forgotten Readers, 191; Elizabeth Long, Book Clubs: Women and the Uses of Reading in Everyday Life (Chicago, 2003), 22, 60-61, 221. 
African Americans in a realistic and non-patronizing light. Conforming to the white conventions of the day, Bradford's black characters speak in dialect, a literary device that has the effect of distancing readers from the characters. The illustrations in the Literary Guild's 1931 edition of John Henry (a series of woodcuts by J. J. Lankes) show black men and women smiling and with exaggerated features in a variety of poses, from swinging a sledgehammer to resting in a rocking chair, loafing on the grass, or playing cards while smoking. A romanticized picture of a little white country church is counterbalanced by an image of two bottles of alcohol. The overall picture of African Americans is one of comical irresponsibility-even childishness. A telling feature of this edition is the inclusion of a review in the end papers of another Bradford book, This Side of Jordan (1929), taken from the Milwaukee Journal: "In rich colorful prose Roark Bradford has conceived this novel of Negro life along the bayous of the lower Mississippi, of these colored folk, whom he has known all of his life. ... His readers are made to feel the pulsing strain of these Negroes, to feel the mystery of the curious spell which the Mississippi holds over them, to understand the deeply ingrained superstitions which rule their lives."

How black readers in the 1930s reacted to such a recommendation can only be imagined. Bradford's work would come under considerable criticism 30 years later, but the fact that at the time he was seen as a "serious interpreter of Negro life in the South" says less about Bradford himself than about other works by white writers at the time that included black characters. ${ }^{35}$ It is also hard to understand why the Book Lovers chose Bradford's book. Perhaps these educated, relatively affluent northern women saw little connection between themselves and the rural southerners in Bradford's story, and did not take offense at his depictions. On the other hand, perhaps they read John Henry in order to critique its explicit racism. ${ }^{36}$ Whatever

35. The phrase "serious interpreter of Negro life in the South," is taken from another review of This Side of Jordan in the same edition of John Henry, this one from The North American Review.

36. Gere, Intimate Practices, 227, points out that in her 1895 address, "The Value of Race Literature," Victoria Earle Matthews (1861-1907) "illustrates a way of reading to counter racist representations ... [b]y showing her peers how to read in ways that affirm African American beliefs and traditions." 
the reasons behind the selection, there can be little doubt that the Book Lovers had to struggle to find books in which African Americans figured as more than servile or comic foils to the principal white actors in the story.

More authentic were the voices of black novelists, poets, and commentators. Perhaps because of the club members' goal of reviewing new books, most of the books written by authors of the Harlem Renaissance during the 1920s are missing from these lists. But the Book Lovers did review Walter White's Fire in the Flint (1924) and Nella Larsen's Passing (1929). They also chose Benjamin Brawley's The Negro in Art and Literature, although it had first been published as long ago as 1918, probably because the publishing house of Duffield reissued it in 1930. Prominent on their lists was W. E. B. Du Bois for his 1928 novel Dark Princess as well as for his sociological works Black Reconstruction (1935) and Dusk of Dawn (1940). In Black Reconstruction, $\mathrm{Du}$ Bois drew attention to the "normal" derogatory depiction of African Americans, railing against the contemporary history of Reconstruction as "propaganda against the Negro ... one of the most stupendous efforts the world ever saw to discredit human beings, an effort involving universities, history, science, social life and religion." 37

During the 1920s, a group of University of Chicago sociologists, led by Robert E. Park (a former secretary to the Tuskegee Institute's principal, Booker T. Washington), had begun to develop an alternative, social scientific theory of race that proposed an analogy between groups based on race and European immigrant groups. At the same time, Progressive Era critics also launched an attack on biological theories of race. During the 1930s, the ethnicity theory, with its emphasis on social and cultural processes, including religion, language, and politics, largely succeeded in replacing biological theories of race. ${ }^{38}$

By reading recent works on the sociology of race, the Book Lovers acquainted themselves with a theory that saw African

37. W. E. Burghardt Du Bois, Black Reconstruction: An Essay Toward a History of the Part which Black Folk Played in the Attempt to Reconstruct Democracy in America, 1860-1880 (New York, 1935), 727.

38. Michael Omi and Howard Winant, Racial Formation in the United States: From the 1960s to the 1990s (New York, 1994), 15. 
American culture as the product of a discriminatory society that could in principle be reformed, rather than as resulting from irredeemably inferior biological characteristics. For instance, they reviewed John Dollard's Caste and Class in a Southern Town (1937), which attempted to do for a small southern town what Helen Merrill Lynd and Robert S. Lynd had done for Muncie, Indiana, in 1929. ${ }^{39}$ In two chapters, Dollard explored issues of racialized aggression in the community he studied. In a chapter titled "Negro Aggression against Whites," he commented that southern white people "show the greatest sensitivity to aggression from the side of the Negro, and in fact, to the outside observer, often seem to be reacting to it when it is not there." By contrast, in the next chapter, titled "White Caste Aggression Against Negroes," Dollard wrote of "the fear that always attends the Negro." "Every Negro in the South," he continued, "knows that he is under a kind of sentence of death; he does not know when his turn will come, it may never come, but it may also be at any time." 40

The Book Lovers also reviewed two works commissioned by the American Youth Commission in the late 1930s and published in 1940: Children of Bondage: The Personality Development of Negro Youth in the Urban South, an in-depth study of eight black teenagers by Allison Davis and John Dollard; and Negro Youth at the Crossways: Their Personality Development in the Middle States, a study of young African Americans living in Washington, DC, and Louisville, Kentucky, by E. Franklin Frazier. These scholarly publications emphasized the role of sociological influences such as community, school, and family and psychological factors resulting from systematic racial subordination.

THROUGH THEIR READING and reviews of books by and about African Americans, the Book Lovers created a means to consider the crucial racial issues of the day for all black Americans. For women, whether black or white, literary and social clubs provided a setting that they themselves could control and in which their voices did not have to compete with those of men.

39. Robert S. Lynd and Helen Merrell Lynd, Middletown: A Study in Contemporary American Culture (New York, 1929).

40. John Dollard, Caste and Class in a Southern Town (New Haven, CT, 1937), 359. 


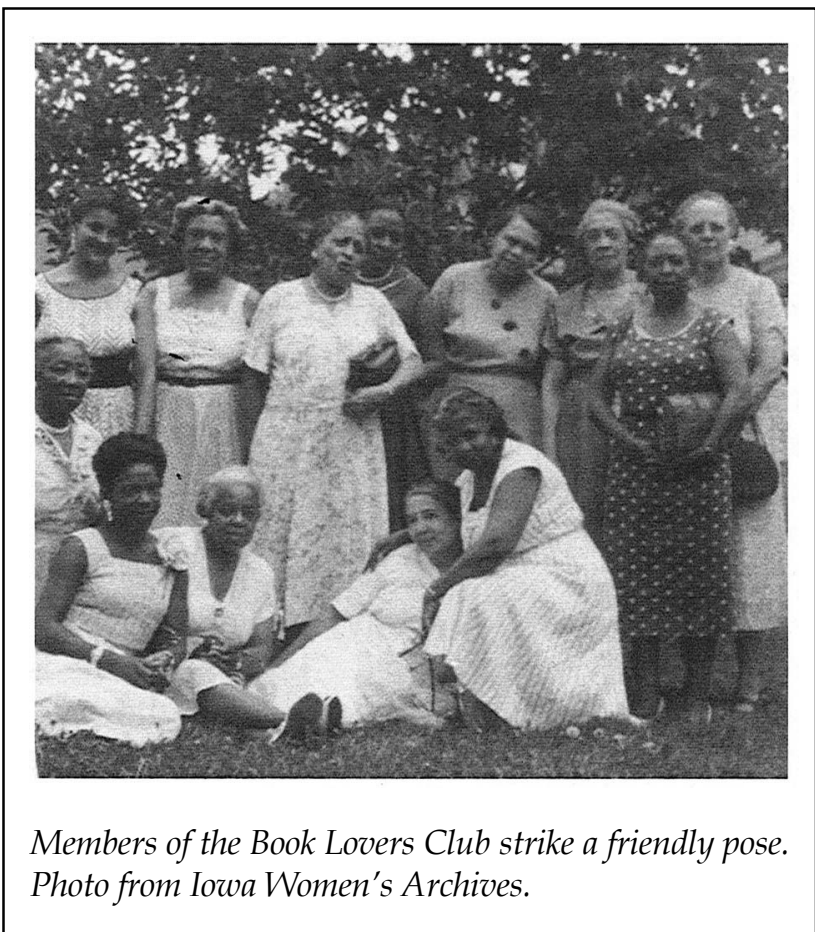

For the Book Lovers, though, possibly of equal importance was the fact that the members were all black - a condition that the YWCA not only facilitated in the 1930s and early 1940s but demanded. That was about to change, however. After World War II, pressure from African Americans finally convinced both the national YMCA and the YWCA to pass a resolution urging white associations to end Jim Crow segregation. In 1946 the YWCA's National Association adopted an "Interracial charter" abolishing segregated YWCAs across the country. ${ }^{41}$

During the 1930s, modest moves towards racial integration had already taken place in the Des Moines YWCA, where some members of the Blue Triangle Branch were attending integrated classes, though this was unusual. In 1931 the first African American woman had been elected as a member of the board of directors, and by the 1940s a movement for greater equality was

41. Nina Mjagkij, Light in the Darkness: African Americans and the YMCA, 18521946 (Lexington, KY, 1994), 1; “One Hundred Years.” 
under way. ${ }^{42}$ At the YWCA's annual meeting in 1944, the Race Committee reported that "there is much tension among both the White and Negro, and especially the employers who are beginning to hire some Negroes. The economic problem is the biggest one for Negroes." The committee "wants us to work toward equal salary for all workers regardless of color, and to promote inter-racial contacts in order for all to have the same opportunities." 43 In May 1946 the Blue Triangle Branch Committee recommended that "the program and program staff of the Blue Triangle Branch be integrated with the Central Branch," and that the by-laws be amended "to provide that there shall be one or more Negro persons on the professional staff of the Des Moines YWCA." 44

On May 14, Y president Madeline Lambert addressed a letter to the board members, highlighting the urgency of integrating the Central and Blue Triangle Branch. Noting that this step would be "in line with experience throughout the country, with the recommendations of the national convention and with our own practice," Lambert argued that it "will make us frankly, what we have long claimed to be - a Christian interracial organization, serving all women and girls without discrimination." Integration would not be easy, she warned. "We will accept many problems if we take this step. We may lose some members whose pride of race rises above their loyalty to the Christian ideal." But integration would also "draw to us those who want to share with us this latest challenge to our faith." 45

At the membership meeting held on June 13, 1946, members voted 61 to 9 to integrate the Blue Triangle Branch with the Central YWCA, and 63 to 4 "to employ a Negro woman on the professional staff." In September of that year, the Blue Triangle Branch's building was sold, and by February 1947, its activities were fully incorporated into the downtown YWCA. "Separate Negro and white clubs at the Des Moines YWCA are now being opened to membership to girls of both races," announced the

42. "One Hundred Years."

43. YWCA Annual Meeting Minutes, 1944, YWCA Records, box 3.

44. Madeline Lambert, president, to board members, 5/14/1946, YWCA Records, box 3 .

45. Ibid. 
Bystander, although Y officials emphasized that "it's up to the girls in the individual clubs whether they want to make their group interracial." 46

No record reveals how the Book Lovers responded to the call for integration in the late 1940s, but they may have been in no rush to seek white members. They must have had mixed feelings about the changes that integration might bring to their club. Would white members be interested in reviewing books by black authors and books about race, or would they have a different agenda? Would white members try to take charge of the club's administration, as they had in the late nineteenth century, when independent black Ys were downgraded to branch status? It would be some years before they would find out.

The Book Lovers remained a club exclusively for African Americans until 1958, when Bothilda "Bo" Cleveland, a tireless opponent of the urban renewal that ultimately destroyed the Center Street neighborhood, became its first white member, opening the way for other white women to join the club. Fortyfive years later, in 1993, her fellow Book Lovers nominated her for special YWCA honors. "Bo took this bold action during a period when integration generally meant that African-Americans sought acceptance into white organization-not the reverse," they wrote. "Bo's action led to other white women joining the Booklovers. A greater interaction between the races resulted. It is said quietly among some senior African-American women that 'Bo Cleveland integrated the YWCA.'" In 1991 Cleveland proposed that the Book Lovers should establish a Memorial Textbook Scholarship to provide to the "deserving and needy student a scholarship for the purchase of college textbooks." Cleveland herself chaired the committee and "typically, provided expert leadership." 47

Despite desegregation, however, the club retained its racial identity over subsequent decades. In 2005 the Book Lovers met to celebrate their eightieth anniversary. Still all women, mainly

46. "YWCA Membership Meeting," 6/13/1946, YWCA Records, box 3; Des Moines Sunday Register, 2/16/1947; The Bystander, 2/20/1947.

47. "Mrs Bothilda 'Bo' Cleveland, Chair, Booklovers Textbook Scholarship Fund," Nominator: YWCA Booklovers, YWCA of Greater Des Moines Nomination Form, 1993, PLDM Archives. 
black, and now almost all retired, they meet monthly in a public library branch to discuss books and to promote reading and education. They sponsor college scholarships, and they talk about politics. At a recent meeting, the discussion became so animated that a library staff member had to ask them to close the door to avoid disturbing the other patrons.

MANY OF THE READING CHOICES the Book Lovers had made in the interwar period suggested that they were making a conscious effort to choose books that would help them explore their identities as black Iowa women living during a period of great social upheaval. Their reading did more than shape individual identities, however. It was also an expression of collective political action - a way to comprehend and to resist the social, cultural, and political conditions that both circumscribed and broadened their lives. Through their memberships in leading churches and other organizations, Book Lovers exercised leadership in Iowa's African American community, and books undoubtedly influenced them in their role as opinion leaders. Reading articles in the nationally distributed Crisis and Opportunity, as well as in the locally influential Iowa Bystander, made them aware of efforts to promote social justice through black print culture. The format of their weekly book reviews encouraged them to see books as potential vehicles for change by requiring them to highlight social and political elements. New developments in the sociology of race, which they learned about through reading, provided them with the theoretical justification as well as the necessary data to support their advocacy for social reform. In addition to fostering their own knowledge and understanding of race through books and articles, they also sponsored public programs featuring black writers, and rented out books to others who perhaps could not afford to buy them. But not all their reading had such a serious purpose. The great majority of the books they chose-best-selling and other popular fiction of the day-were undoubtedly sources of considerable pleasure. The Book Lovers appreciated printed materials for their political and informational value, but like other Americans of the time, it seems, they also just liked to read. 